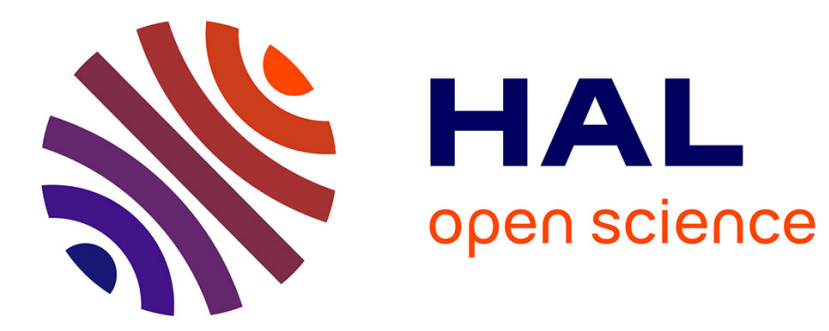

\title{
A scientific note on a new assay to measure honeybee mite-grooming behavior
}

\author{
Gladys Andino, Greg Hunt
}

\section{To cite this version:}

Gladys Andino, Greg Hunt. A scientific note on a new assay to measure honeybee mite-grooming behavior. Apidologie, 2011, 42 (4), pp.481-484. 10.1007/s13592-011-0004-1 . hal-01003573

\section{HAL Id: hal-01003573 https://hal.science/hal-01003573}

Submitted on 1 Jan 2011

HAL is a multi-disciplinary open access archive for the deposit and dissemination of scientific research documents, whether they are published or not. The documents may come from teaching and research institutions in France or abroad, or from public or private research centers.
L'archive ouverte pluridisciplinaire HAL, est destinée au dépôt et à la diffusion de documents scientifiques de niveau recherche, publiés ou non, émanant des établissements d'enseignement et de recherche français ou étrangers, des laboratoires publics ou privés. 


\title{
A scientific note on a new assay to measure honeybee mite-grooming behavior
}

\author{
Gladys K. Andino, Greg J. Hunt \\ Department of Entomology, Purdue University, 901 West State Street, West Lafayette, IN 47907, USA
}

Received 22 February 2010 - Revised 16 June 2010 - Accepted 11 July 2010

chewed mites / Varroa destructor / Apis mellifera

For breeding bees that tolerate Varroa mites, one strategy is to select stocks that survive without using measures to control mites. However, it may be more efficient to select for specific traits that confer resistance so that multiple traits can be combined in resistant stock. Two behavioral traits have been identified that suppress population growth of Varroa mites. One of these traits is Varroa sensitive hygiene, which has been incorporated into a breeding program that made stock available to beekeepers (Harbo and Harris 1999, 2005; Ibrahim and Spivak 2004, 2006; Rinderer et al. 2010). The other trait is grooming behavior (Arechavaleta-Velasco and Guzmán-Novoa 2001). Mite-grooming behavior has been associated with higher proportions of mutilated mites falling from bees in colonies (Arechavaleta-Velasco and GuzmánNovoa 2001) and the proportion of mutilated mites was associated with lower infestation levels (Moosbeckhofer 1992; Arechavaleta-Velasco and Guzmán-Novoa 2001; Mondragón et al. 2005). However, measuring the proportion of chewed mites in a breeding program is extremely laborious because most mutilated mites are only missing legs, and one must be careful not to damage the mites prior to making observations. One laboratory assay involved observing the reaction of individual bees when mites were placed upon them (Aumeier, 2001). Several cage assays for grooming behavior have been developed, but these assays required collecting and counting mites

Corresponding author: G.K. Andino, gandino@purdue.edu

*Manuscript editor: Peter Rosenkranz to artificially infest a small number of bees. Results of these assays have not been directly correlated with the proportion of chewed mites in colonies, but they did show differences between low- and high-grooming lines (Arechavaleta-Velasco and Guzmán-Novoa 2001; Currie and Tahmasbi 2008). Here, we describe a mitegrooming assay that relies on the natural infestation of the bees and does not require determining the number of bees tested.

From May through August 2009, 31 colonies were used to develop a mite-grooming assay. Wooden cages $(52.5 \times 27 \times 7.2 \mathrm{~cm})$ were built capable of containing one frame covered with bees (Figure 1). The top and the bottom of the cages were made of metal screen (eight openings per $2.54 \mathrm{~cm}$ ). A wooden gas chamber was built to hold the cages to anesthetize the bees with carbon dioxide. From each of the selected colonies, bees from several frames in the brood nest were shaken into the cage, and a frame with only nectar and pollen and no brood was placed inside the cage. An entire frame of bees was used to ensure sufficient number of mites and bees to obtain reliable data on grooming behavior. A white plastic board $(50.9 \times 38.8 \mathrm{~cm})$ was used to collect the mites. Each board was labeled to indicate the colony being assayed and was coated with canola oil using a brush. The cages were then placed on wood supports $(45 \times$ $1 \times 1.9 \mathrm{~cm})$ above the plastic boards at room temperature $\left(22^{\circ} \mathrm{C}\right.$ to $\left.25^{\circ} \mathrm{C}\right)$. The mites that dropped onto the oil during the first $72 \mathrm{~h}$ were then collected and counted. The remaining mites on the adult bees were collected by placing each cage inside the gas chamber and releasing $34.47 \mathrm{kPa}$ of carbon dioxide $\left(\mathrm{CO}_{2}\right)$ for $30 \mathrm{~s}$. The gas valve was then closed, and the bees 


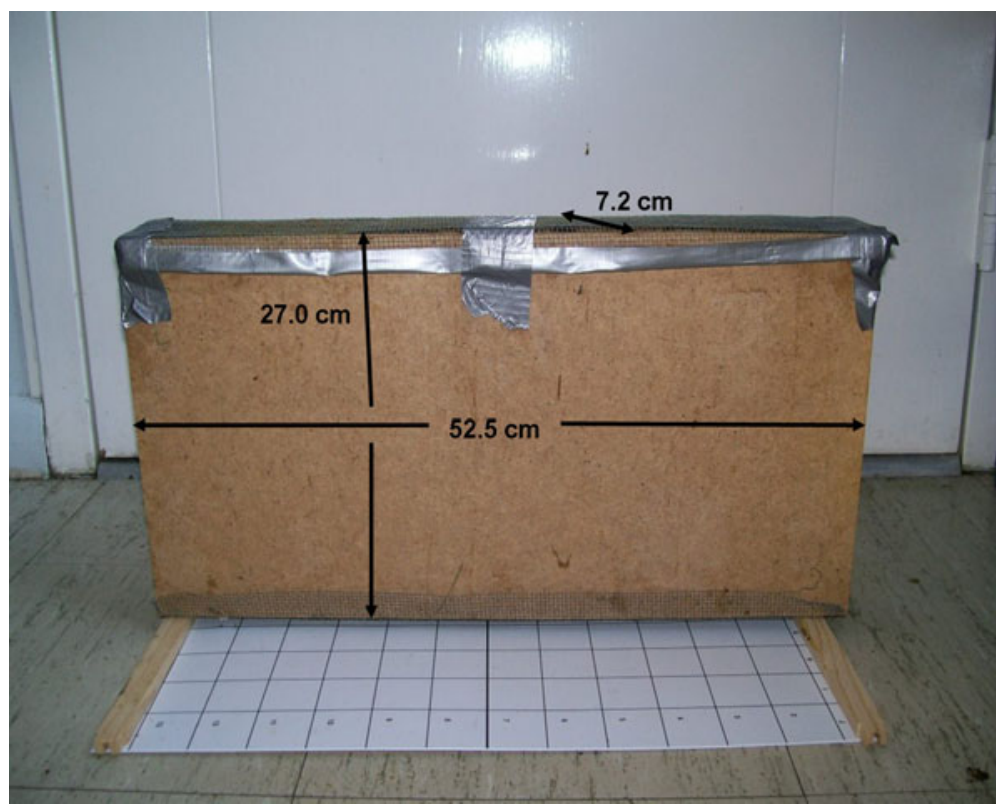

Figure 1. Wooden cage $(52.5 \times 27 \times 7.2 \mathrm{~cm})$ capable of holding one frame covered with bees.

were exposed to the gas for an additional $1.5 \mathrm{~min}$. Anesthetized bees were placed inside of a plastic container sealed with a metal screen, and the bees were weighed to estimate the total of mites per unit of bee weight. The total weights of the bees ranged from 71.42 to $357.14 \mathrm{~g}$. After the bees were partially revived, $30 \mathrm{~g}$ of powdered sugar was added to the bees inside the container. After sitting for $2 \mathrm{~min}$, the container was shaken upside down multiple times, and the mites present on the adult bees were collected on a sheet of white plastic and counted. The proportion of mites removed was calculated by dividing the number of mites removed during the grooming period by the total number of mites (mites that fell during $72 \mathrm{~h}$ plus mites remaining on adult bees).

The proportion of chewed mites that dropped from the cages was not determined, but the proportion of mutilated mites from sticky boards in the source colonies was counted to be able to compare the percentage of chewed mites with the results of the lab assay. Mites were considered to be chewed if they were missing legs or parts of legs, or if they had a part of the outer edge of the idiosoma missing. These mutilations are easy to differentiate from the "dorsal dimples" that were described by Davis (2009). These counts were done approximately 1 month after the lab assay. Sticky boards were placed under screens at the bottom of each of the 31 colonies in the field. After $72 \mathrm{~h}$, the sticky boards were collected and placed in the freezer separated by wooden spacers to preserve the mites until they were counted. The mites from each sticky board were removed, mounted legs up on microscope slides, inspected, and counted for damage in the idiosoma and amputation or mutilation of one or more legs. The percentage of chewed mites was calculated.

A significant positive correlation was found between the proportion of mites removed in the lab assay and the proportion of chewed mites on sticky boards from the source colonies $\left(r^{2}=0.231 ; P=0.006\right.$; log-transformed data). This relationship indicates that the colonies that removed the highest percentage of mites in the caged bees were also the colonies that had the highest percentage of chewed mites (Figure 2a). These results show that the method used to measure mite-grooming behavior is effective. In addition, we also found a significant negative correlation between the percentage of mites removed and the mite infestation of adult bees $\left(r^{2}=-0.367 ; P<\right.$ 0.001 ; log-transformed data), which indicates that the colonies with the highest percentage of mites removed in the cage assay had the lowest population of mites on adult bees (Figure 2b). These results suggest that the low population of mites present on the adult bees was due to grooming. This method should be suitable for screening sufficient numbers of colonies to select for grooming behavior in breeding programs 

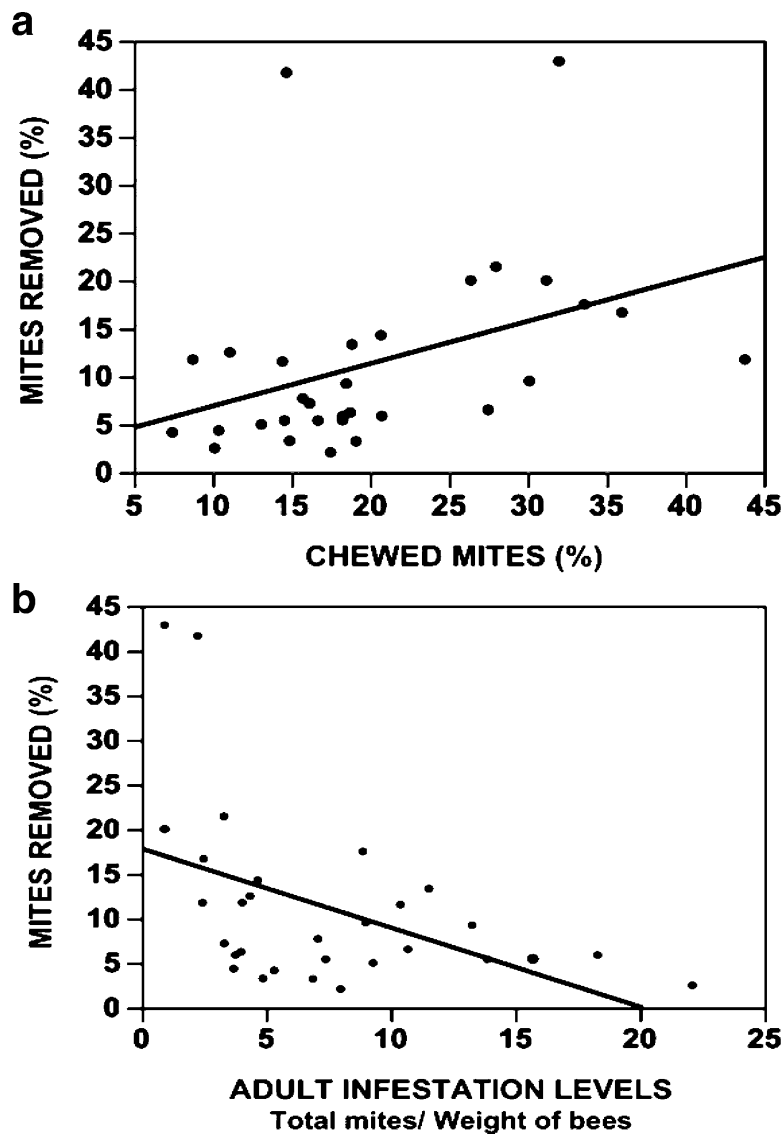

Figure 2. a Positive linear relationship between the percentage of mites removed in the cage assays and the percentage of chewed mites that fell from colonies $\left(r^{2}=0.231 ; n=31 ; P=0.006\right)$. Graph presents raw data, but statistical analysis was performed on log-transformed data to approximate a normal distribution. b Negative linear relationship between the percentage of mites removed in cage assays and mite infestation of adult bees $\left(r^{2}=-0.367 ; n=31 ; P<0.001\right)$. Graph presents raw, data but statistical analysis was performed on logtransformed data to approximate a normal distribution.

and could be valuable for research of mite-grooming behavior. The main limitation is the number of cages that can be constructed and the time and labor required to collect the bees and to count mites. We speculate that using an entire frame full of bees is important because mite infestations were sometimes fairly low. The range for the total number of mites in these cages was from five to 199. The two outliers that appear in (Figure 2a) are two out of the five colonies with the lowest number of mites (seven and 12). Perhaps this assay works best when the infestation levels of mites are relatively high. The assay is still fairly laborious and should be considered only as a possible alternative to determining the proportion of mutilated mites on sticky boards, but our assay seems to solve one problem that has faced researchers, that of having a test that mimics colony conditions in cages. In these queenless cages, the bees would sometimes buzz loudly for short periods, especially during the afternoons. It appears that the presence of a queen and brood is not needed to stimulate significant amounts of grooming behavior. It should also be noted that the assay appears to work over a fairly broad range of bee samples. We shook between 70 and $350 \mathrm{~g}$ of bees into the cages, but the average weight of bees used was $161.73 \mathrm{~g}$. 


\section{ACKNOWLEDGEMENTS}

This work was funded by the USDA Honey Bee Health Coordinated Agricultural Project 2009-8511805718 and a North Central IPM SARE award. We are grateful to Alicia Kelly and Krispn Given for the valuable technical assistance.

Note scientifique sur une nouvelle méthode pour mesurer le comportement de toilettage des abeilles contre les acariens.

\section{Eine wissenschaftliche Notiz über eine neue Methode zur Erfassung des Grooming-Verhaltens von Honigbienen gegenüber Varroamilben.}

\section{REFERENCES}

Arechavaleta-Velasco, M.E., Guzmán-Novoa, E. (2001) Relative effect of four characteristics that restrain the population growth of the mite Varroa destructor in honey bee (Apis mellifera) colonies. Apidologie 32, 157-174

Aumeier, P. (2001) Bioassay for grooming effectiveness towards Varroa destructor mites in Africanized and Carniolan honey bees. Apidologie 32, 81-90
Currie, R.W., Tahmasbi, G.H. (2008) The ability of high- and low-grooming lines of honey bees to remove the parasitic mite Varroa destructor is affected by environmental conditions. Can. J. Zool. 86, 1059-1067

Davis, A.R. (2009) Regular dorsal dimples on Varroa destructor - damage symptoms or developmental origin? Apidologie 40, 151-162

Harbo, J.R., Harris, J.W. (1999) Selecting honey bees for resistance to Varroa jacobsoni. Apidologie 30, 183-196

Harbo, J.R., Harris, J.W. (2005) Suppressed mite reproduction explained by the behaviour of adult bees. J. Apic. Res. 44, 21-23

Ibrahim, A., Spivak, M. (2004) The relationship between suppression of mite reproduction (SMR) and hygienic behavior. Am. Bee. J. 144, 406

Ibrahim, A., Spivak, M. (2006) The relationship between hygienic behavior and suppression of mite reproduction as honey bee (Apis mellifera) mechanisms of resistance to Varroa destructor. Apidologie 37, 31-40

Mondragón, L., Spivak, M., Vandame, R. (2005) A multifactorial study of the resistance of Africanized and hybrid honeybee Apis mellifera to the mite Varroa destructor over one year in Mexico. Apidologie 36, 345-358

Moosbeckhofer, R. (1992) Observations on the occurrence of damaged Varroa mites in natural mite fall of Apis mellifera carnica colonies. Apidologie 23, 523-531

Rinderer, T.E., Harris, J.W., Hunt, G.J., De Guzman, L.I. (2010) Breeding for resistance to Varroa destructor in North America. Apidologie 41, 409-424 